\title{
STRATEGI OPTIMALISASI PENGHIMPUNAN DANA NASABAH \\ BAGI PERKUATAN PERMODALAN DI BMT MAWADDAH \\ KANTOR CABANG PANDAAN PASURUAN
}

\author{
Aulia Laita M. dan Renny Oktafia \\ Universitas Muhammadiyah Sidoarjo \\ Email: aulialaita258@gmail.com dan renny.oktafia@umsida.ac.id
}

\begin{abstract}
The purpose of this study was to determine the strategy for optimizibg customer fund collection at BMT Mawaddah Kantor Cabang Pandaan Pasuruan Branch Office. The method used in this reserach is qualitative method. Data collection techniques used in thid study are observation, interviews and documentation. The result of this research is BMT Mawaddah Pasuruan Branch Office in managing customer funds the strategy used is a pick-up system to pomote products owned by BMT Mawaddah to the community.
\end{abstract}

Keyword: BMT, Strategy, and Fundraising.

\begin{abstract}
Abstrak
Tujuan penelitian ini adalah untuk mengetahui strategi optimalisasi penghimpunan dana nasabah pada BMT Mawaddah Kantor Cabang Pandaan Kantor Cabang Pasuruan. Metode yang digunakan dalam penelitian ini adalah metode kualitatif. Teknik pengumpulan data yang digunakan dalam penelitian ini adalah observasi, wawancara dan dokumentasi. Hasil dari penelitian ini adalah BMT Mawaddah Kantor Cabang Pasuruan dalam mengelola dana nasabah. Strategi yang digunakan adalah sistem penjemputan produk pomote milik BMT Mawaddah kepada masyarakat.
\end{abstract}

Kata Kunci: BMT, Strategi, dan Penghimpunan Dana. 


\section{PENDAHULUAN}

Dalam perkembangannya lembaga keuangan syariah baik yang bank maupun non bank tidak terlepas dari perannya suatu Lembaga Keuangan Mikro Syariah (LKMS). Seperti BaitulMaal Wattamwil (BMT), Koperasi Jasa Keuangan Syariah dan lain-lain. LKMS ini sangatlah penting bagi perkembangan lembaga keuangan syariah memiliki peran yang sangatlah penting, mengapa demikian, karena lembaga keuangan mikro inilah yang nantinya mampu dapat menjangkau transaksi keungan syariah pada ruang lingkup mikro seperti yang berada pada pedesaan atau didaerah yang tidak bisa dilayani oleh lembaga bank umum maupun lembaga bank yang membuka unit syariah (Roviana, 2017).

Lembaga keuangan mikro syariah telah memiliki segmen pasar yang sudah jelas yaitu masyarakat kalangan kecil, sehingga kegiatan LKMS akan berpusat pada sentra bisnis masyarakat level mikro dan menengah seperti pasar tradisional, wilayah usaha kecil dan menengah, serta lingkungan masyarakat perdesaan dan pinggiran perkotaan. LKMS memiliki karakteristik yang dekat dengan masyarakat bahkan tidak jarang LKMS berusaha untuk datang pada masyarakat (jemput bola), hal ini yang membuat LKMS menjadi populer dan dekat dengan masyarakat. Lahirnya lembaga keuangan mikro syariah ini memperlihatkan kecenderungan yang semakin baik di tengah krisis global yang melanda negeri ini. Banyak produk yang ditawarkan cukup Variatif sehingga para nasabah dapat memilih sesuai dengan kebutuhannya (Muhammad, 2010).

Lembaga Keuangan Mikro Syariah (LKMS) adalah salah satu satu jenis lembaga keuangan non bank yang melakukan penghimpunan dan penyaluran dana kepada masyarakat kecil, seperti zakat, infak, shadaqah, dan juga pembiayaan modal usaha. Dengan adanya LKMS diharapkan menjadi solusi alternatif yang lebih fleksibel untuk membantu dan meningkatkan perekonomian masyarakat kecil dibandingkan dengan bank yang lebih menjangkau kepada masyarkat kalangan ke atas. Selain itu LKMS juga diharapkan agar dapat menjadi pilihan bagi masyakat kecil agar dapat terhindar dari praktek-praktek ribawi yang saat ini telah marak di sekitar lingkungan tempat tinggal (Arifin, 2014).

Baitul Maal Wattamwil(BMT) adalah lembaga keuangan non bank yang dananya bersumber dari masyarakat yang nantinya akan di salurkan kembali kepada masyarakat dalam bentuk pembiayaan atau pinjaman dengan sistem bagi hasil. Sehingga dalam pengoperasiannya menggunakan sistem bagi hasil dan berbagai produk yang telah dibuat sesuai dengan syari'at Islam (Ridwan, 2004).

Pengoptimalisasian peran BMT ini diperlukan agar pertumbuhan usaha menengah kecil mikro meningkat sehingga juga akan berdampak pada pertumbuhan ekonomi masyarakat yang meningkat. Oleh karena itu perlu adanya pengoptimalisasian peran BMT dari dua sektor yaitu optimalisasi dari sektor penghimpunan dan penyaluran dana. Apabila dua sektor ini dijalankan dengan baik dan juga dioptimalkan maka fungsi dan peran BMT akan berjalan dengan lancar. Tujuan daripengoptimalisasian peran BMT pada penghimpunan dan penyaluran dana adalah sebagai bentuk upaya agar dapat meningkatkan perekonomian masyarakat kecil menengah dan sebagai bentuk respon LKMS terhadap kebutuhan nasabah.

Salah satu lembaga keungan mikro syariah yang ikut serta dalam melakukan strategi penghimpunan dana dalam mengoptimalisasikan penguatan permodalan yakni pada BMT Mawaddah. BMT Mawaddah ini berlokasi di Jl. Dr. Soetomo Komplek Ruko Candra No. 4 Dusun Sukun Sumbergedang, Pandaan, Pasuruan, Jawa Timur 67153. BMT Mawaddah ini merupakan cabang ke 12 dimana kantor pusatnya berlokasi pada pamekasan, BMT Mawaddah Kantor Cabang Pandaan Pasuruan telah berdiri selama 1 tahun. BMT Mawaddah pada cabang ini memilik 4 pegawai yang menjalankan kegiatan operasionalnya.

Keberhasilan lembaga keuangan dalam menjalankan kegiatan amanah yang 
telah diberikan oleh masyarakat dalam menjalankan kegiatan operasionalnya tidak terlepas dari adanya suatu perencanaan sistem dan strategi yang dikembangkannya terutama dala mengelola penghimpunan dana dari masyarakat, oleh karena itu penulis ingin mengetahui lebih dalam tentang bagaimana strategi penghimpunan dana yang diterapkan dan strategi yang digunakan oleh BMT Mawaddah Kantor Cabang Pandaan Pasuruan dalam mengelola dan mengembangkan usahaha dan amanah yang telah diberikan oleh masyarakat sehingga dapat berhasildalam mengelola dana dengan baik, karena keberhasilan itu dapat meyakinkan kepercayaan masyarakat kepada BMT Mawaddah Kantor Cabang Pandaan Pasuruan.

\section{LITERATURE REVIEW}

Penelitian tentang strategi penghimpunan dana juga pernah dilakukan oleh Nur Asaroh dengan judul penelitian "Strategi Penghimpunan Dana Pada Produk Simpanan El Amanah Dengan Akad Wadiah Yad Adh Dhamanah di BMT El Amanah Kendal." Metode penelitian yang digunakan dalam penelitian ini adadalh metode kualitatif. Kesimpulan dari penelitian ini menunjukkan bahwa BMT El Amanah memilik produk simpanan El Amanah yang mana bentuk tabungannya menggunakan pada prinsip Wadiah Yad Dhamanah yang dapat disetor dan diambil sewaktu-waktu dan dapat memberikan hasil yang menguntungkan dari hasil usaha BMT El Amanah. Strategi yang dilakukan oleh BMT El Amanah sudah efisiensi dengan melakukan penyebaran brosur, promosi, dan memberikan pelayanan yang memuaskan kepadad para anggota nasbahnya, strategi penjualan dan strategi dari mulut ke mulut juga dilakukan oleh BMT El Amanah.

Penelitian yang dilakukan oleh Nurul Afifah yang berjudul "Strategi Penghimpunan Dana Simpanan Akad Wadiah dan Mudharabah Berbasis Sekolah di BMT Permata Jawa Timur." Penelitian ini bertujuan untuk mengetahui tentang strategi penghimpunan dana dalam produk simpanan yang menggunakan akad wadiah dan mudharabah yang berbasis pada sekolah di BMT Permata Jawa Timr dan faktor apa saja yang menghambat dalam mengelola penghimpunannya di BMT Permata Jawa Timur. Metode yang digunakan dalam penelitian ini adalah pendekatan kualitatif dan deskriptif. Hasil yang diperoleh dalam penelitian adalah strategi penghimpunan dana yang dijalankan oleh BMT Permata Jawa Timur yakni pada layanan jemput bola. Model jemput bola manual inilah yang dapat menghasilkan beberapa kemudahan untuk BMT Permata Jawa Timur dalam memasarkan beberapa produk yang dimilikinya.

Penelitan yang pernah dilakukan oleh Dwi Prasetya Hartama memiliki judul "Strategi Penghimpunan Dana Pada Produk Tabungan BSM Dengan Akad Mudharabah Muthlaqah di Bank Syariah Mandiri KC Permatangsiantar." Penelitian ini bertujuan untuk mengetahui tentang prosedur operasional produk tabungan BSM dengan akad Mudharabah Muthlaqah dan untuk mengetahui strategi pemasaran yang digunakan dalam penghimpunan dan produk tabungan BSM. Metode yang digunakan dalam penelitian ini adalah metode penelitian kualitatif. Hasil yang diperoleh dari penelitian ini adalah Bank Syariah Mandiri mempunyai strategi pemasaran dalam mengembangkan produknya seperti dengan cara individu, kelompok, presentasi, dan menyebarkan brosur. Sasaran dari tabungan ini adalah untuk semua kalangan.

Dari beberapa topik penelitian yang telah dipaparkan di atas, ternyata belum ada tinjauan secara khusus dan komprehensif tentang strategi optimalisasi penghimpunan dana untuk perkuatan permodalan di BMT Mawaddah Kantor Cabang Pandaan Pasuruan. Oleh karena itu, diharapkan penelitian ini mampu mengungkapkan mendeskripsikan dan menganalisis lebih jauh sesuai dengan perkembangan saat ini. Di sinilah letak perbedaan studi ini dengan studistudi yang telah dilakukan sebelumnya. 
METODE PENELITIAN

\section{Jenis Penelitian}

Penelitian ini membahas tentang strategi optimalisasi penghimpunan dana nasabah bagi perkuatan permodalan BMT. Peneliti akan melakukan penelitian secara langsung di BMT Mawaddah Kantor Cabang Pandaan Pasuruan guna untuk mengetahui tentang strategi optimalisasi penghimpunan dana nasabah bagi perkuatan permodalan BMT. Penelitian ini akan menjelaskan serta menganalisa obyek yang akan diteliti yaitu tentang strategi optimalisasi penghimpunan dana nasabah bagi perkuatan permodalan oleh BMT, sehingga peneliti memilih menggunakan penelitian kualitatif. Metode penelitian kualitatif merupakan penelitian yang digunakan untuk meneliti pada kondisi obyek yang alamiah yang berlandaskan pada filsafat postpositivisme dimana peneliti adalah sebagai instrumen kunci.

Metode yang digunakan dalam penelitian ini adalah metode kualitatif. Metode kualitatif adalah metode penelitian yang digunakan untuk mendalami dan memahami pemahaman berdasarkan metodologi yang bersifat menganalisa fenomena keadaan sosial masyarakat (Sugiyono, 2015). Pendekatan penelitian yang digunakan peneliti yaitu studi kasus. Studi kasus dan deskriptif. Studi kasus proses elaborasi dan pendeskripsian sebuah masalah yang diteliti pada masyarakat secara mendalam untuk mempelajari latar belakang, situasi sosial, dan hubungan sosial yang berlangsung (Yin, 2004).

\section{Lokasi Peneltian}

Peneliti akan melakukan penelitian di BMT Mawaddah Kantor Cabang Pandaan Pasuruan untuk mendapatkan data tentang strategi optimalisasi penghimpunan dana nasabah bagi perkuatan permodalan BMT. Peneliti melakukan penelitian hanya disatu perusahaan, karena ingin mendapatkan hasil yang maksimal untuk memenuhi data yang dibutuhkan.

Alamat : Jl. Dr. Soetomo Komplek Ruko Candra No.4 Dusun Sukun
Sumbergedang, Pandaan, Pasuruan, Jawa Timur 67153

No. HP : : 085851108775

\section{Teknik Pengumpulan Data}

\section{a. Observasi}

Observasi adalah pengamatan secara langsung terhadap gejala-gejala yang akan diteliti dan pencatatan dilakukan secara sistematik terhadap hal-hal yang berkaitan dengan strategi penghimpunan dana. Observasi menjadi salah satu teknik pengumpulan data apabila sesusai dengan tujuan penelitian, direncanakan dan dicatat secara sistematis, serta dapat dikontrol kendalan dan kesahihannya (Margono, 2005).

Peneliti memilih teknik observasi terus terang atau tersamar dengan alasan peneliti dalam melakukan pengumpulan data menyatakan terus terang kepada sumber data yang telah dipilih oleh peneliti, bahwa peneliti sedang melakukan penelitian. Sehingga sumber data mengetahui sejak awal sampai akhir tentang aktivitas peneliti. Sebelum melakukan observasi, peneliti sudah menentukan hal-hal yang akan diteliti di antaranya tentang apa saja yang akan dilakukan dalam tahapan observasi ini. Jadi dalam observasi ini peneliti mendatangi secara langsung BMT Mawaddah Kantor Cabang Pandaan Pasuruan sehingga peneliti akan lebih dekat dengan informan dan lebih bisa mendapatkan data sesuai yang diinginkan. Untuk lebih mengetahui tentang mengatur strategi penghimpunan dana dalam mengoptimalisasikan perkuatan permodalan BMT peneliti memilih ikut langsung dalam kegiatan dan aktivitas kantor, tujuannya agar secara langsung berhadapan dengan seluruh pegawai yang ada di BMT Mawaddah Kantor Cabang Pandaan Pasuruan.

\section{b. Wawancara}

Wawancara adalah teknik pengumpulan data atau informasi dengan 
cara mengajukan pertanyaan kepada informansecara lisan dan dijawab secara lisan(Suharsaputra, 2014). Wawancara ini dilakukan hanya kepada seluruh pegawai BMT Mawaddah Kantor Cabang Pandaan Pasuruan seperti kepala cabang, teller, customer service, dan marketing.

\section{c. Dokumentasi}

Pada penelitian ini dokumen yang dimaksud yaitu berbentuk tulisan hasil wawancara, gambar maupun rekaman hasil wawancara, jurnal-jurnal yang digunakan sebagai pelengkap dari penggunaan metode wawancara serta dokumentasi dalam penelitian kualitatif (Suharsaputra, 2014).

Teknik dokumentasi merupakan suatu cara pengumpulan data yang menghasilkan catatan-catatan penting berhubungan dengan masalah yang diteliti sehingga akan diperoleh data yang lengkap, sah, dan bukan berdasarkan pada perkiraan dengan mengambil data yang sudah ada dan tersedia dalam catatan dokumen (Sugiyono, 2018).

\section{KONSEP DASAR}

\section{Pengertian Strategi}

Strategi merupakan suatu kegiatan perencaan yang komperhensif yang melibatkan beberapa faktor guna untuk memenuhi tercapainya suatu tujuan yang diharapkan dalam sebuah organisasi atau perusahaan (David, 2002).

Strategi pemasaran merupakan strategi yang memiliki bagian integral dari suatu strategi bisnis yang dapat memberikan arahan pada semua fungsi manajemen suatu organisasi bisnis atau perusahaan. Sebab, pemasaran itu sendiri merupakan aktivitas perencanaan, pelaksanaan dan pengawasan atas program-program yang dirancang untuk menghasilkan transaksi melalui target-target yang sudah menjadi program dalam suatu bisnis (Bakhri, Leliya \& Purnama, 2018).

Dalam lembaga keuangan kegiatan pemasaran juga perlu dilakukan guna untuk memenuhi beberapa tujuan yang akan dicapai, baik tujuan dalam jangka pendek maupun tujuan dalam jangka panjang. Dalam jangka pendek biasanya lembaga keuanga digunakan untuk merebut nasabah terutama untuk memperkenalkan produk-produk yang baru kepada nasabah yang dikeluarkan oleh suatu lembaga keuangan. Sedangkan dalam jangka panjang suatu lembaga keuangan yang akan dilakukan ialah untuk tetap mempertahankan produk-produk yang sudah ada agar tetap terus dikembangkan lebih baik lagi.

\section{Bauran Pemasaran}

Proses pemasaran adalah proses tentang bagaimana pengusaha dapat mempengaruhi konsumen agar para konsumen tersebut menjadi tahu, senang lalu membeli produk yang ditawarkannya dan akhirnya konsumen menjadi puassehingga akan slalu membeli produk pada perusahaan itu. Bagaimana caranya pengusaha itu agar dapat memperngaruhi konsumennya merupakan hal yang memerlukan perencanaan dan pengawasan yang matang serta perlu dilakukan tindakan-tindakan yang terprogram. Bauran pemasaran merupakan alat yang dapat dipergunakan oleh pengusaha guna untuk mempengaruhi konsumennya.

Strategi bauran pemasaran adalah salah satu unsur dalam strategi pemasaran terpadu. Bauran pemasaran (marketing mix) merupakan alat yang digunakan dalam pemasaran yang terdiri dari berbagai unsur yakni, yang terdiri atas harga produk, promosi, dan distribusi yang perlu dipertimbangkan agar implementasi strategi pemasaran positioning yang ditetapkan dapat berjalan dengan sukses sesuai dengan harapan yang diinginkan. Bauran pemasaran barang ini berbeda dengan bauran pemasaran yang untuk pada produk jasa hal ini dikarenakan denga adanya perbedaan karakteristik jasa dan barang

\section{Strategi Promosi}

Penjualan merupakan sebuah produk usaha yang telah dibuat dan dilakukan oleh manusia guna untuk menyampaikan suatu kebutuhan yang mana produk yang telah telah dihasilkanditawarkan kepada mereka 
yang memerlukannya dengan imbalan yang berlandaskan pada harga atau dengan cara dibelinya produk yang ditawarkan tersebut. Dalam sebuah proses penjualan tidak dapat terlepas dari suatu perencanaan strategi yang efektif. Dalam strategi promosi yang diajalankan akan berkaitan dengan masalah-masalah pelaksanaan, perencanaan,dan pengendalian komunikasi yang baik dengan para pelanggannya (Lupiyoadi \& Hamdani, 2006).

2. Strategi Produk

Pengertian produk adalah semua produk yang dimiliki yang nantiny ditawarkan kepada pasar untuk mendapat perhatian, dimiliki, dan dikonsumsi, yang dapat memuaskan keinginan atau kebutuhan konsumen (Suharno \& Sutarso, 2010).

3. Strategi Harga

Harga adalah satu-satunya dalam
unsur bauran pemasaran yang memberikan pemasukan dan pendapatan perusahaan dari produk yang telah ditawarkan oleh perusahaan. Sedangkan dalam unsur lainnya produk, distribusi dan promosidapat menyebabkan pengeluaran untuk perusahaan (Tjiptono, 1997).

4. Strategi Tempat

Tempat dalam bidang usaha ialah lokasi dimana tempat usaha tersebut dijalankan, dalam hal ini tempat juga memiliki hubungan dengan para konsumennya dimana para lokasi tersebut dapat menyampaikan bahwa lokasi usah yang ditempati strategi. Penentuan lokasi kantor juga harus disertai dengan sarana dan prasarana pendukung yang menjadi kebutuhan yang penting dalam melayani para konsumennya. Agar para konsumennyamudah menjangkau setiap lokasi usaha tersebut (Lupiyoadi \& Hamdani, 2006).

\section{Penghimpunan Dana}

Penghimpunan dana adalah kegiatan usaha lembaga keuangan dalam menarik dan mengumpulkan dana-dana dari masyarakat dan menampungnya dalam bentuk simpanan, giro, tabungan, deposito/surat berharga lainnya. Simpanan merupakan dana yang dipercayakan oleh anggota, calon anggota atau koperasi lain dalam bentuk simpanan dan simpanan berjangka(Soemitra, 2009).

Dalam penghimpunan dana (funding) akan diupayakan dlaam merancang suatu perencanaan yang matang hal ini dilaukan agara dalam menghimpun dana dilakukan dengan cara yang baik sebagaimana mestinya, tidak hanya itu untuk dapat menarik minat masyarakat agar mau bergabung dalam lembaga keuangan tersebut. Dalam melakukan kegiatan penghimpunana dana yang dilakukan oleh suatu lembaga keuangan adlaah adanya saling kepercayaan, yang artinya masyarakat dapat percaya kepada lembaga keunagan yang menhimpun dananya, dengan demikian lembaga keuangan dapat menarik para masyarak untuk menimpan dananya. Sama seperti yang dilakukan oleh BMT dalam melakukan penghimpunan dana ini yang pada prinsipnya adalah amanah, maka diharapkan seluruh para pegawaina dapat mengelola dana masyarakat yang amanah sesuai dengan prisni-prinsip syariah. Karena BMT sendriri memiliki peran sebagai penghimpun dan penyalur dana dari masyarakat yang telah diamanat kepada BMT tersebut (Nurhatati \& Rahmaniyah, 2008).

\section{Perkuatan Permodalan}

Menurut Bambang Riyanto menjelaskan bahwa pengertian modal usaha adalah yang mana ikhisar neraca dalam perusahaan menggunakan modal konkrit dan modalabstrak. Modal konkrit yang ini dimana sebagai modal aktif sedangkan modal abstrak yang ini dimana sebagai modal pasif (Riyanto, 1997).

\section{Baitul Maal Watt Tamwil (BMT)}

Baitul Maal Wattamwil (BMT) terdiri dari dua istilah yaitu Baitul maal dan Baitul Tamwil. Secara harfiah/lughowi Baitul Maal berarti rumah dana dan Baitul tamwil berarti 
rumah usaha. Baitul maal dikembangkan berdasarkan sejarah perkembangannya, yakni dari masa nabi sampai abad pertengahan perkembangan Islam. Dimana baitul maal berfungsi untuk mengumpulkan sekaligus mentasyarufkan dana sosial. Sedangkan baitul tamwil merupakan lembaga bisnis yang bermotif laba

Baitul Maal wat Tamwil (BMT) adalah balai usaha mandiri terpadu yang isinya berintikan bayt al-maal wa al-tamwil dengan kegiatan mengembangkan usahausaha produktif dan investasi dalam meningkatkan kegiatan ekonomi pengusaha kecil denga cara mendorong kegiatan menabung dan menunjang pembiayaan kegiatan ekonominya (Soemitra, 2009).

\section{HASIL dan PEMBAHASAN}

\section{Sejarah Berdirinya BMT Mawaddah} Kantor Cabang Pandaan Pauruan

Bait al-Mal wa at-Tamwil (BMT) Mawaddah merupakan sejarah berdirinya Bait al-Mal wa at-Tamwil (BMT) Mawaddah merupakan salah satu unit usaha yang bergerak dibidang ekonomi yang berada dibawah naungan Koperasi al-iqtishad lil-Muamalah (KOIM) Mawaddah syariah Jawa Timur. Berawal dari pendirian KOIM pada bulan April tahun 1993, Kemudian muncul lembaga keuangan syariah BMT Mawaddah.

BMT Mawaddah merupakan representasi dari sebuah lembaga keuangan shariah bertaraf mikro ekonomi yang merupakan lembaga keuangan asset ummat dengan pola kebersamaan melalui kegiatan tabungan, pembiayaan serta kegiatankegiatan lain yang berdampak pada peningkatan ekonomi anggota atau nasabah serta mitra ke taraf yang lebih sejahtera, aman dan berkah.

Sebagai lembaga keuangan shariah yang mengemban misi sosial ekonomi ummat, BMT Mawaddah selalu berbenah diri terutama dari segi kualitas pelayanan dan pengelolaan sehingga menjadi sebuah lembaga yang sesuai dengan visi dan misi yang diembannya. Lembaga ini secara tidak langsung merupakan asset ummat yang dalam pelaksanaan operasionalnya mengacu pada prinsip-prinsip shari'ah islam.

Pertama kali BMT Mawaddah ini berdiri, hanya ada satu cabang yaitu bertempat dipondok pesantren miftahul ulum panyepen dengan oprasional sederhana. Namun semakin banyaknya nasabah yang bergabung dengan BMT Mawaddah, maka ditingkatkan pula fasilitas dan kualitas pelayanannya seperti penggunaan mesin penghitung uang serta pembangunaan uang serta pembangunan gedung beserta seluruh fasilitas pendukung lain seperti pelatihan karyawan AC, CCTV,dan lain sebagainya.

Dalam perjalanannya BMT Mawaddah kini mengalami peningkatan dan perkembangan yang cukup signifikan dan maju, dalam kegiatan usaha BMT Mawaddah dalam memenuhi kebutuhan dan pemintaan dari para nasabah dalam kegiatan transaksi keuangan syariah. Perkembangan ini tidak lain adanya dukungan dari para Alumni Pesantren Miftahul Ulum, para santri, para wali santri, seluruh simpatisan ataupun masyarakat banyak yang membuat BMT Mawaddah kini bisa membuka cabang di berbagai daerah terlebih di pulau madura, sudah terhitung 17 cabang kantor usaha di berbagai daerah. Hal ini membuat perkembangan BMT Mawaddah ikut serta dalam menjawab kebutuhan masyarakat dan juga mampu bersaing secara regional karena sekarang sudah berjalan kantor cabang di Pandaan Pasuruan.

\section{Produk Penghimpunan Dana BMT Mawaddah Kantor Cabang Pandaan Pasuruan}

Produk penghimpunan dana yang dimiliki oleh BMT Mawaddah Kantor Cabang Pandaan Pasuruan terdapat 12 produk yang pengelolaan dananya dilakukan secara amanah diantaranya :

1. Tabungan Mudharabah Umum

2. Tabungan Wadiah Yad Amanah

3. Tabungan Wadiah Yad Dhamanah

4. Tabungan Wadiah Yad Dhamanah Berjangka

5. Tabungan Tarbiyah 

6. Tabungan Idul Fitri
7. Tabungan Idul Adha
8. Tabungan Ibadah Qurban
9. Tabungan Walimah
10. Tabungan Akikoh
11. Tabungan Ziarah Wisata Islami (WISMI)
12. Tabungan Perumahan

\section{Strategi Penghimpunan Dana Nasabah di BMT Mawaddah Kantor Cabang Pandaan Pasuruan}

Dalam melakukan kegiatan menghimpun dana nasabah strategi yang digunakan oleh BMT Mawaddah Kantor Cabang Pandaan Pasuruan adalah strategi sistem jemput bola. Dalam sistem jemput bola ini dilakukan sebagai tempat promosi dan sosialisasi secara lebih optimal di masyarakat. Pengelola BMT dalam memasarkan produknya yang merupakan dapat meningkatkan keberhasilan di suatu lembaga. Untuk dapat meningkatkan keberhasilan yang efektif dalam memasarkan produknya dan dapat mencapai target pemasaran produk yang dimiliki oleh BMT diawal operasionalnya adalah dengan cara melakukan pendekatan "Jemput Bola". Pendekatan ini dilakukan oleh petugas BMT secara langsung untuk mendatangi calon nasabah dan petugas akan menjelaskan dengan leluasa mengenai konsep keuangan syariah, serta sistem dan operasional yang digunakan oleh BMT Mawaddah Kantor Cabang Pandaan Pasuruan. Dari hasil wawancara yang telah dilakukan oleh peneliti terhadap narasumber dimana adalah Bapak Moh Wadi selaku Kepala Cabang BMT Mawaddah Pandaan Pasuruan. Mengemukakan ada beberapa strategi yang digunakan dalam menghimpun dana di BMT Mawaddah yaitu:

1. Strategi Promosi

Dalam strategi promosi yang dilakukan oleh BMT Mawaddah mneggunakan strategi pendeketan individual dimana strategi ini melalui promo yang dilakukan dengan promosipromosi melalui brosur yang kemudian dapat dijual secara langsung atau jemput bola. Istilahnya adalah pihak BMT Mawaddah Kantor Cabang Pandaan Pasuruan mendatangi langsung kepada calon nasabah, yang kemudian menawarkan produk-produk yang dimiliki oleh BMT, baik itu produk penghimpunan dana maupun produk pembiayaan. Hal itu dilakukan dengan tujuan untuk bisa mendapatkan dana dari nasabah.

Strategi yang digunakan oleh BMT Mawaddah Kantor Cabang Pandaan Pasuruan dalam menghimpun dana itu dengan cara promosi. Promosi ini dilakukan apabila terdapat produkproduk baru yang dimiliki oleh BMT Mawaddah Kantor Cabang Pandaan Pasuruan dan dengan cara sistem jemput bola karena hali ini merupakan langkah awal yang akan memumngkinkan petugas BMT Mawaddah dapat memberikan penjelasan mengenai konsep-konsep keuangan syariah, sistem dan prosedur yang berlaku dalam operasionalnya BMT Mawaddah secara leluasa, sekaligus merupakan solusi bagi mereka yang memiliki tingkat kesibukan tinggi sehingga tidak memliki cukup waktu untuk dapat berkunjung langsung ke BMT Mawaddah. Pendekatan jemput bola ini merupakan salah satu cara yang efektif yang dapat dilakukan dalam mencapai target-target memasarkan produk yang dimiliki oleh BMT Mawaddah di awal operasionalnya, karena sebagai lembaga keuangan yang belum lama berdiri, BMT Mawaddah membutuhkan promosi dan sosialisasi secara optimal kepada masyarakat.

Jadi dalam sistem jemput bola

BMT Mawaddah selalu aktif untuk mendatangi nasabah dalam menghimpun dana nasabah, akan tetapi bukan berarti tidak ada nasabah yang datang ke kanor untuk menabung. Hal ini disebabkan karena pada umumnya nasabahnya adalah para pengusaha kecil yang kegiatan sehari-harinya berdagang dipasar sehingga mereka tidak 
mempunyai banyak waktu untuk datang ke kanntor secara langsung. Sistem jemput bola ini mempermudah nasabah dalam menanbung, karena nasabah tidak perlu meninggalkan usahanya untuk pergi ke kantor BMT Mawaddah.

Dari semua informasi yang didapat oleh peneliti dapat disimpulkan bahwa strategi promosi bertujuan untuk menyampaikan dan mempromosikan produk-produk yang dimiliki oleh BMT Mawaddah supaya dikenal oleh nasabah dan juga untuk dapat menjalin komunikasi yang baik dengan nasabah. Hasil yang dilakukan oleh BMT Mawaddah dapat dilihat dari total dana dalam produk penghimpunan dana nasabah Pada tahun 2019, Rincian Simpanan yang dimiliki oleh BMT Mawaddah, pada peiode 2019 mengalami pertumbuhan simpanan, dimana BMT Mawaddah memilik modal awal pada tahun 2018 sebesar Rp. 350.000 .000 , tingkat pertumbuhan yang dialami oleh BMT Mawaddah ini dapat ditunjukan oleh tabel berikut ini :

\section{Tabel 1. Simpanan Tabungan}

\begin{tabular}{|c|c|c|}
\hline No & Simpanan & Jumlah \\
\hline 1 & Tabungan Umum & Rp. 253.952.000 \\
\hline 2 & Tabungan Berjangka & Rp. 406.500 .000 \\
\hline \multirow[t]{4}{*}{3} & Tabungan Anggota & \\
\hline & 1. Tabungan Pokok & Rp. $\quad 53.100 .000$ \\
\hline & 2. Tabungan Wajib & Rp. $\quad 65.620 .000$ \\
\hline & Total Simpanan & Rp. 779.172.000 \\
\hline & er: BMT Mawaddah & Kantor Cabang \\
\hline
\end{tabular}

Jika dilihat dari data diatas BMT Mawaddah mengalami pertumbuhan dana simpanan dengan presentase $70 \%$. Mengingat bahwa BMT Mawaddah Kantor Cabang Pandaan Pasuruan ini baru didirikan pada bulan September tahun 2018 yang telah mengalami pertumbuhan dengan baik dalam mengelola dana simpanan nasabahnya.

Dengan adanya nasabah yang mempercayakan dana nya untuk dikelola oleh BMT hal itu juga akan terjadi untuk memperkuat permodalan yang ada di BMT Mawaddah. Ini artinya strategi yang digunakan cukuplah efektif dalam menghimpun dana nasabah.

2. Strategi Harga

Dalam strategi harga pada BMT Mawaddah yakni telah ditetapkan oleh pimpinan atas. Strategi harga dari tabungan yang biasa digunakan oleh yakni tabungan mudharabah umum, tabungan ini dapat diambil kapanpun dan dimana saja yang nasabah mau. Dalam hal ini BMT Mawaddah tidak membebankan nasabah pada saat pembukaan maupun penutupan rekening. Pada saat pembukan rekening baru yang dilakukan oleh calon nasabah di BMT Mawaddah tidak ada biaya, akan tetapi untuk setoran awal atau saldo awal minimal dilakukan oleh nasabah minaimal Rp. 10.000 yang kemudian setoran selanjutnya dapat dilakukan oleh nasabah minimal Rp.5.000. Setoran awal yang dilakukan oleh nasabah guna untuk mendapatkan bagi hasil. Jika nasabah ingin melakukan penutupan rekening atau menutup buku tabungan nasabah hany mengganti uang buku tabungan sebesar Rp. 5.000.

Dengan demikian BMT Mawaddah dalam pembukaan rekening calon nasabah tidak dibebani oleh biaya apapun, akan tetapi jika nasabah melakukan penutupan rekening maka nasabah akan dibebani total uang yang sebesar Rp. 5.000 sebagai bentuk mengganti uang buku tabungan.

3. Strategi Produk

BMT Mawaddah Kantor Cabang Pandaan mempunyai beberapa produkproduk yang dimiliki dan dipromosikan pada masyarakat. Setiap produk yang dimiliki oleh BMT Mawaddah memiliki keunggulan masing-masing. Seperti pada produk tabungan mudharabah umum, tabungan ini adalah yang paling favorit di nasabah. Karena dalam produk tabungan ini dapat diambil kapanpun dan dimana 
saja, jadi nasabah juga gaperlu datang langsung ke kantor BMT Mawaddah ketika mengambil uang tabungan, karna pegawai BMT Mawaddah dapat mengantarkan lan gsung kepada nasabah.

Dengan demikian stratetgi produk yang dilakukan oleh BMT Mawaddah bahwasannya terdapat beberapa keunggulan dengan menabung di BMT Mawaddah, diantaranya adalah adanya kemudahan dalam bertransaksi yakni dengan sistem jemput bola yang dilakukan, yang mempermudah nasaba dalam hal menabung maupun menarik tabungan, jadi nasabah tidak perlu datang langsung ke kantor BMT Mawaddah Kantor Cabang Pandaan Pasuruan, terdapat sistem bagi hasil dan terhindar dari riba.

4. Strategi Tempat

Strategi tempat yang dipilih oleh BMT Mawaddah sebagai tempat kantor atau lokasi sudah dianggap strategis, dengan alasan memang dekat dengan pasar Pandaan karena untuk dapat sosialisai langsung pada masyrakat. Dengan demikian BMT Mawaddah memiliki tempat dekat dengan pasar adalah untuk memudahkan bersosialisasi yang dilakukan oleh BMT Mawaddah dengan masyrakat sekitar.

\section{Dampak Strategi Penghimpunan Dana Nasabahdi BMT Mawaddah Kantor Cabang Pandaan Pasuruan}

Dari beberapa strategi yang digunakan oleh BMT Mawaddah Kantor Cabang Pandaan Pasuruan memiliki dampak dari setiap strategi yang dilakukan oleh BMT Mawaddah yakni, dalam strategi promosi, harga, produk dan tempat yang dilakukan oleh BMT Mawaddah memiliki dampak yang cukup baik. Walaupun terdapat persaingan ketat dari lembaga keuangan lainnya, namun BMT Mawaddah mampu mengembangkan produk-produk yang yang dimiliki dengan strategi yang digunakan oleh BMT Mawaddah.
BMT Mawaddah ini baru berdiri pada tahun 2018 namun dengan strategi yang digunakan oleh BMT Mawaddah mampu bersaing dengan lembaga keuangan lainnya. Dengan demikian dari seluruh strategi yang digunakan oleh BMT Mawaddah Kantor Cabang Pandaan Pasuruan dalam mengelola penghimpunan dana nasabah dalam upaya untuk memperkuat permodalan tentu memiliki dampak yang cukup baik. Hal ini dapat dilihat berdasarkan pada tabel diatas mengenai total dana produk simpanan pada BMT Mawaddah Kantor Cabang Pandaan.

Melihat dari data diatas BMT Mawaddah mengalami pertumbuhan dana simpanan yang cukup signifikan. Mengingat bahwa BMT Mawaddah Kantor Cabang Pandaan Pasuruan ini baru didirikan pada bulan September tahun 2018. dalam menarik nasabah untuk melakukan simpanan tabungan pada BMT Mawaddah. Oleh sebab itu, dampak dari strategi penghimpunan dana nasabah di BMT Mawaddah Kantor Cabang Pandaan Pasuruan dalam menghimpun dana cukup baik.

\section{KESIMPULAN}

Dari strategi BMT Mawaddah Kantor Cabang Pandaan Pasuruan menggunakan beberapa strategi dalam mengembeangkan produkproduk yang dimilikinya, yakni strategi promosi, harga, produk dan tempat. Dalam strategi yang digunakan oleh BMT terdapat sistem jemput bola dimana sistem ini untuk mempromosikan produk-produk yang dimiliki oleh BMT Mawaddah pada masyarakat. Dengan beberapa strategi yang digunakan oleh BMT Mawaddah mengalami perubahan yang cukup signifikan dalam mengelola penghimpunan dana dari nasabah dan strategi yang digunakan sangatlah optimal.

Dampak yang dialami oleh BMT Mawaddah cukup baik dalam mengelola penghimpunan dana nasabah. Atas strategi yang digunakan oleh BMT Mawaddah dalam mempromosikan produknya, mengalami peningkatan. 


\section{DAFTAR PUSTAKA}

Arifin, M. A. (2014). Pengembangan Produk-Produk Lembaga Keuangan Syariah. Equilibrium, 157-173.

Bakhri, S., Leliya., \& Purnama, L., (2018). Tinjauan Etika Bisnis Islam dalam Strategi Pemasaran Home Industri Tahu Sari Rasa. Al-Mustashfa: Jurnal Penelitian Hukum Ekonomi Islam, 3(2). 284-299. http://dx.doi.org/10.24235/jm.v3i2.3 686

David, F. R. (2002). Manajemen Strategi Konsep. Jakarta: Prenhalindo.

Fitri, M. (2016). Peran Dana Pihak Ketiga Dalam Kinerja Lembaga Pembiayaan Syariah Dan Faktor-Faktor Yang Memengaruhinya. Economica: Jurnal Ekonomi Islam, 7(1), 73-95. https://doi.org/10.21580/economica. 2016.7.1.1033

Gatot, H., Shinta, D., \& Goenawan. (2012). Sistem Penghimpunan Dan Penyaluran Dana Masyarakat Pada BRI Unit Manda. Akuntansi \& Keuangan, 3(1), 107-122.

Khornelis, D., \& Yusrialis. (2016). Tantangan Pengembangan Baitul Mal Wat-Tamwil Di Pekan Baru Riau. Jurnal Kajian Ekonomi Islam, 1(2).

Lara, S. Y. (2013). Pengaruh Dana Pihak Ketiga, Kecukupan Modal Dan Risiko Kredit Terhadap Profitabilitas (Perusahaan Perbankan Yang Terdaftar di BEI). $E$ Journal.Unp.Ac.Id, 1-25.

Lupiyoadi, R., \& Hamdani, A. (2006). Manajemen Pemasaran Jasa. Jakarta: Salemba Empat.

Margono. (2005). Metode Penelitian Pendidikan. Jakarta: Rineka Cipta.

Muhammad, R. (2010). Akuntansi Keuangan Syariah. Yogyakarta: P3EI Press.

Nurhatati, F., \& Rahmaniyah, S. (2008). Koperasi Syariah. Surakarta: PT Era Intermedia.

Nurul, B. N. O. (2016). Strategi Penghimpunan Dana Sosial Ummat Pada Lembaga-Lembaga Fillantrofi
Di Indonesia (Studi Kasus Dompet Peduli Ummat Darurat Tauhid, Dompet Dhuafa Republika, BAZNAS, dan BAZIS DKI jakarta). Jurnal Studi Ekonomi Dan Bisnis Islam, I, 22-34.

Ratna, S. Y., \& Romi, S. (2016). Aktivitas Penghimpunan Dana Pada PT. Bank Pembangunan Sumatera Barat Cabang Painan. Jurnal Ekonomi, V, $1-14$.

Ridwan, M. (2004). Manajemen Baitul Maal Wa Tamwil. Yogyakarta: UII Press.

Riyanto, B. (1997). Pengangguran Modal: Dasar-dasar Pembelajaran Perusahaan (3rd ed.). Yogyakarta: BPEE.

Roviana, E. (2017). Analisis Pengaruh Persepsi Harga atau Margin dan Kualitas Terhadap Minat Anggota dalam Membeli Produk Pembiayaan Murabahah di Koperasi Jasa Keuangan Syariah (Studi Kasus BMT Amal Mulia). Stain Salatiga.

Sanwani, Titiek, H., \& Akhmad, J. (2017). Strategi Penghimpunan Dan Penyaluran Dana Pada Baitul Maal Wat Tamwil (Bmt) Al-Hidayah Di Kabupaten Lombok Timur. Jurnal Lembaga Keuangan Dan Perbankan, 2(1).

https://doi.org/10.21154/justicia.v14i 1.1219

Soemitra, A. (2009). Bank Dan Lembaga Keuangan Syariah (2nd ed.). Jakarta: Kencana Predana Group.

Sugiyono. (2018). Metode Penelitian Kuantitatif Kualitatif dan $R \& D$ (27th ed.). Bandung: Alfabeta.

Suharno, \& Sutarso, Y. (2010). Marketing in Practice. Yogyakarta: Graha Ilmu.

Suharsaputra, U. (2014). Metode Penelitian Kuantitatif, Kualitatif, Dan Tindakan. Bandung: Refika Aditama.

Supeno, W. (2017). Analisis Kinerja Penghimpunan Dana dalam Meningkatkan Penyaluran Kredit pada Bank Perkreditan Rakyat. Jurnal Moneter, IV(oktober), 121-131. 
Retrieved

from

http://ejournal.bsi.ac.id/ejurnal/index .php/moneter/article/view/2336

Tjiptono, F. (1997). Strategi Pemasaran (2nd ed.). Yogyakarta: Andi.

Utama, S., \& Handini, P. E. (2017). Inovasi Produk Penghimpunan Dana Perbankan Syariah (Studi Kasus Tabungan Arisan BPRS Madina ). In the 5th Urecol Proceeding, 4, 908-
919.

Yin, R. K. (2004). Studi Kasus: Desain Dan Metode. Jakarta: Raja Grafindo Persada.

Ziara, W. I. (2013). Strategi Penghimpunan Dana Pihak Ketiga Pada PT. BTN (Persero) Tbk Cabang Magelang. EJournal.Unp.Ac.Id, 1(2), 23-45. 